
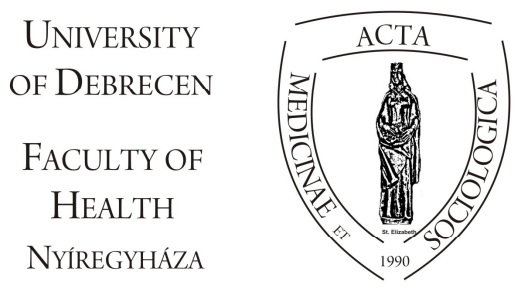

ACTA

MedSoc

VOLUME 8.

2017

\title{
A siker értelmezése a büntetés-végrehajtás keretei között
}

\author{
Pénzes Marianna
}

Állami Egészségügyi Ellátó Központ

\begin{abstract}
Absztrakt. Tanulmányunkban a siker narratíváját vizsgáljuk fogvatartottak körében félig strukturált kérdőívvel készített interjúk elemzésével. A kutatás 2015 májusában zajlott a Szabolcs-Szatmár-Bereg Megyei Büntetés-végrehajtási Intézetben. A lezajlott kutatás során megkérdezett 13 fő szavaiban sajátos, idealisztikus jövő konstrukció fogalmazódik meg. A szabadságvesztés nem kudarcként vagy egy tanulási folyamat részeként jelenik meg, hanem jelenlegi helyzetüket sokkal inkább egyfajta parkoló pályaként jelenítik meg, ahonnan különösebb feltételek nélkül vissza lehet térni a hétköznapi életbe. Társas kapcsolataik elvesztését elsősorban a család támogatása ellensúlyozza, szakmai karrierjük, jövedelemszerzésük véleményük szerint tovább folytatható (döntően a legalitás keretei között), ehhez nem élik meg saját személyiségük, magatartásuk jelentős változtatásának szükségességét. A kutatás eredményei is megerősítik a bünelkövetők személyiség-fejlesztésének szükségességét. Sikeres reintegrációjukhoz, a bünismétlés elkerüléséhez nélkülözhetetlen az önismeret és életkészségek fejlesztése, valamint a társadalmi normák és elvárások megértése, az egyéni és közösségi érdekek összehangolása.
\end{abstract}

Kulcsszavak: siker, börtön, reintegráció

Abstract. In our study we examine the success-narratives among prison inmates with analysis interviews we elaborated using semistructured questionnaires during May of 2015 in the Szabolcs-Szatmár-Bereg County's Prison Service Institute. In frame of study the interviewed inmates (13 persons) constructed a particular, idealistic future-picture. Loss 
of freedom appealed as a parking space from where easy to return into weekday life without any special conditions, and they don't look at imprisonment as a defeat nor as a part of learning process. Their family counterweighs the loss of partnerships, from their view's point they can continue professional carrier and income generating (mostly in frame of legality), to this they don't consider the significant changing of their behaviour as necessary. Results of our study reinforced the needs of development offenders' personality; to their successful reintegration, avoiding re-offending there is essential the development of self-knowledge and life skills, moreover unavoidably important to understanding social norms and expectations, harmonizing private and community interests.

Keywords: success, prison, reintegration

DOI: $10.19055 / \mathrm{ams} .2017 .8 / 25 / 8$

\section{Elméleti keretek. A siker szociális reprezentációja}

A ,siker” szóra a Google internetes kereső program több mint 5210 ezer találatot jelentett meg, mutatva ennek a fogalomnak a népszerüségét és megjelenését életünk minden szférájában. A témák igazán sokfélék: sikertréning, siker-sztorik minden féle megközelítésben (pl. gazdaság, müvészet, tudomány), a sikeres nő, a sikeres férfi, a siker titkai, a legsikeresebbek szokásai stb. ${ }^{1}$

A siker, mint az emberi cselekvések fő motivációja napjainkban különös karriert fut be, társadalomtudósok próbálják a szó legbelső tartalmát megfogalmazni és megmutatni azokat az erőforrásokat, körülményeket, feltételeket, eszközöket, amelyek segítenek a siker megélésében, elérésében.

Váriné Szilágyi Ibolya és Solymosi Zsuzsa Mertont idézve írja, hogy „,... a siker kultúra- és rétegspecifikus szociális reprezentációi befolyásolják az egyének és csoportok magatartását". A siker szociális reprezentációját értelmiségi rétegeknél vizsgálták, tanulmányukban rámutatnak, hogy a siker elsősorban a társadalmi dimenziókban jeleníthető meg (tartalmazza az elismerést és a társadalmi helyzetben való előrehaladást), és a képességek és személyes erőfeszítések mellett az észlelt-becsült társadalmi mozgástér jelentős befolyással bír. (Váriné és Solymosi, 1995)

A siker olyan társadalmi konstrukció, mely a hétköznapokban hétköznapi kapcsolatokban jelenik meg, tükrözi a tágabb társadalmi-kulturális domináns elvárásokat, de egyben maguk az érintettek is befolyásolják, alakítják. A siker jelentése kultúra, nem, etnikum és osztályfüggő is. Nem csupán egy adott ország, társa-

\footnotetext{
${ }^{1}$ https://www.google.hu/search?q=siker\&ie=utf- $8 \&$ oe=utf- $8 \&$ client=firefoxb\&gfe_rd=cr\&ei=BcSQV_bKFaOh8weFyq_wCw
} 
dalmi réteg, etnikai hovatartozás befolyásolja a siker jelentését, hanem ugyanabban a kontextusban is ölthet más jelentést a személy eltérő narratíváján keresztül (az életszakaszok, életfordulópontok másfajta megközelítést, értelmezést, jelentőséget adhatnak a sikernek). A siker tartalma, értékpreferenciája tükrözi a társadalom aktuális értékrendszerét, változó súllyal jelenhet meg benne az anyagi siker, a társadalmi elismerés, magasabb státusz, széleskörü kapcsolatrendszer. (Schleicher, 2015)

A siker szociális reprezentációjában az egyéni és kollektív siker-narratívák együttesen jelennek meg, egymásra hatva, a kollektív jelentésvilág szorosan öszszefügg az egyéni mentális folyamatokkal. László János, (2000) Jovchelovich alapján úgy tartja, hogy a szociális reprezentációk a személyközti valóság terében jelennek meg, de az egyéni pszichikumban fejeződnek ki. Jellemző a szociális reprezentációkra a változás, terjedés, alakulás, ahogyan a társadalomban is folyamatosnak tekinthető a változás. Követve a szociális reprezentáció elméletét, a siker fogalom - ahogyan , ,... a reprezentáció fogalma az egyénit és a társadalmit, nem elválasztja, hanem összekapcsolja” - a csoport, adott társadalmi közeg, valamint az individuális sajátosságok kölcsönös egymásra hatásában megszülető fogalom, melyben, ha van is egyfajta konszenzus, az a valóság talaján sok esetben sajátos metamorfózison esik át.

Különösen érdekes kérdés, hogy a vizsgálatunkba bevont sajátos célcsoport hogyan építi be a siker fogalmát saját belső vilá gába, hogyan használja a tartalmi elemeket a büntetés letöltése utáni életszakaszra a személyes célok megfogalmazásában, stratégiák-tervek konstruálásában, mennyiben tükröződnek ezekben a siker-reprezentációkban az adott originális társadalmi csoport valamint a börtön világában kialakult és az érintett által elfogadott, illetve az öt befogadó csoport értékrendje?

László János korábban hivatkozott cikkében utal Lewin, Asch és Heider elméleteire, miszerint a szociális világ ingerei az egyéni elkülönült tudatokban képeződnek le, és ebben többek között nagy szerepe van a társak által adott ítéleteknek és interpretációknak, illetve ezek elfogadásának. ${ }^{2}$

\footnotetext{
2 „A kognitív szociálpszichológusok is elkülönült egyéni tudatokat feltételeznek, amelyekkel szemben állnak, illetve amelyekben leképeződnek a szociális világ ingerei. .... Lewin szerint a cselekvést meghatározó élettér a személy mindenkori szubjektív valóságának terminusaiban írható le. Asch szerint egy tárgy értékelését és a vele szembeni viselkedést megelőzi az interpretáció, a tárgy szubjektív jelentésének kialakulása. Még a nevezetes konformitáskísérletek értelmezésében is - a társak általi elfogadás igénye és az elutasítás kerülése mellett - hangsúlyozta a társaknak azt a szerepét, hogy a személyeknek információt szolgáltatnak arról, miként kell a tárgyat értelmezni. A társak által adott ítéletek elfogadását Asch szerint megelőzi a társak által nyújtott interpretáció elfogadása" (László, 2000)
} 
Felmerül a kérdés a siker esetében, hogy a fogalom tartalmi elemeivel jellemezhetők-e a büntetés-végrehajtás rendszerében kialakuló csoportok, esetleg a fogvatartottak a siker-narratíváikban inkább a korábbi csoportsajátosságokat tükrözik, színezve az egyéni életutak megélt történései által formálódott egyéni értékekkel vagy inkább a siker-teremtés lehetőségeiről szóló diszkurzusokat tapasztaljuk meg. „...ha arról van szó, hogy minden lehetséges, akkor a konstruálás aktusa nem annyira a valóság kreativ szabadsága, de sokkal inkább e szabadság feltételeiről szött illúzió" - idézi Moscovici szavait László János korábban már hivatkozott írásában (László, 2000: 293). Jelen tanulmányban a siker-konstruálás fogvatartottak körében megjelenő egyéni formáit vizsgáljuk.

A börtönbüntetés intézményi keretei között ma már számtalan program segíti a fogvatartottak sikeres társadalmi reintegrációját, a normakövető magatartás visszaállítását. Ebből a szempontból érdekes kérdés, hogy a szociális reprezentáció elméletére alapozva hogyan alakulnak ki illetve hogyan terjednek pl. a siker fogalmi keretei. Pszichológiai vagy inkább környezeti-társas tényezők befolyásolják? Esetünkben a fogvatartottak siker-képét az egyéni tudás, tapasztalat vagy inkább a környezetből, különösképpen a médiából jövő információk vagy modellélmények (az adott közösség kiemelkedö/kiemelkedőnek tartott modell-személyiségek vagy a média által alakított ,álom-kép” személyek) alakítják?

A büntető igazságszolgáltatásban egyfajta paradigma váltás ment végbe a XXI. században, az elzárás és büntetés funkció mellett egyre nagyobb hangsúllyal jelenik meg a társadalmi reintegráció, reszocializáció feladata. Hosszú távon gazdasági és társadalmi érdek is, hogy a bủnelkövetővé válást és a visszaesést megelőzzük, mértékét csökkentsük.

A börtön világát felülreprezentáló alacsony iskolázottságú, döntően férfi és nagyszámban a marginalizált roma etnikumhoz tartozó csoportok siker narratívájáról, a siker fogalom sajátos szociális reprezentációjáról nincs empirikus előzmény. Ezért is tartjuk fontosnak a tárgyalt interjúk elemzését, melyek rámutatnak a fogvatartottak sikerfogalmára illetve a sikerfogalom mögötti sikerideológiákra és társadalmi preferenciákra.

Az interjúkban nemcsak arra kérdeztünk, hogy mit is jelent a megkérdezett számára a siker, hanem arra is, hogy hogyan képzeli el a jövőjét, vagyis milyen karrier utat lát reálisnak, milyet tervez. Ez utóbbi kérdés vizsgálatához használhatjuk a R. Larson, K. R Brousseau, K. Kling, P. L Sweet (2007) tanulmányában bemutatott karrierút típusokat:

- Szakértöi: ez tekinthető a leginkább olyan tradicionális karrierfogalomnak, amiben gondolkodni szoktunk. Hosszú távú elkötelezettséggel jár, fontos szerepet kap a tudás és a szakértelem, a személyes identitás meghatározója.

- Lineáris: ennek a karrierfogalomnak a legfontosabb ismérvét a ranglétrán való felfelé haladás lehetősége jelenti az ember életében. Felelősség, vezető szerepre 
való törekvés jellemzi, az irányítás és a fontos döntések meghozatala jelenti a kihívást és a karrier értelmét.

- Spirális: ez a karrierút bizonyos időközönként - jellemzően 5-7 évente - viszonylag jelentős változást hoz az ember szakmai életútjában. A biztos szakmai alapok mellett nélkülözhetetlen elem a folyamatos fejlődés, fejlesztés.

- Átmeneti: ez a karrierút-fogalom nem más, mint ,a következetlenség következetes mintázata", mivel az egyetlen állandó elem ebben a folyamatos változás. Az ebbe a csoportba tartozók folyamatosan változtatják munkájukat, e mögött persze nem feltétlen a „mindent tudás”, hanem a „semmi sem sikerül eléggé” tapasztalat is megjelenhet.

A fenti karrier-típusok gazdaságilag aktív, foglalkoztatott középosztálybeli emberekre érvényesek, az általunk vizsgált börtönpopuláció ettől eltérő, így a korábban bemutatott sikeres karrierutak várhatóan eltérően jelennek meg.

\section{Kutatás és módszere}

A Szabolcs-Szatmár-Bereg Megyei Büntetés-végrehajtási Intézetben a Szociális és Munkaügyi Minisztérium támogatásával KAB HAT 08-0057 modell program („Visszatér a fény” címmel) valósult meg, ennek keretében 2008 májusában „Stressz és stresszkezelés. Nyíregyháza, 2008.” kutatási adatfelvétel zajlott. Az önkitöltős kérdőíves vizsgálat lebonyolításában és a kérdezőbiztosi munkában a Debreceni Egyetem Szociológia Tanszékének II. éves szociológus hallgatói (terepgyakorlat keretében) müködtek közre. A kérdöívben elsősorban az általános jólléttel, a legfontosabb életkészségekkel valamint a negatív stressz hatásaival összefüggő tünetekre kérdeztek rá. A vizsgálat során kapott eredményeket a hazai kutatások eredményeivel vetették össze (Murányi, 2009).

Sok érdekesség mellett jelen tanulmány témájához kapcsolódóan érdemes kiemelni az alábbi eredményeket:

- az észlelt stressz (Észlelt Stressz Kérdőív) a kedvezőbb szülői háttérrel és a kedvezőbb munkaerő-piaci helyzettel jellemezhetők körében szignifikánsan alacsonyabb, mint az alacsony iskolázottsággal bíró szülőkkel és kvalifikációt nem vagy kevéssé igénylő munkát (segédmunka, betanított munka) végzők csoportjában;

- a magyar felnőtt lakosság reprezentatív mintáján kapott eredményekhez viszonyítva a börtönlakók szubjektív életminősége (pszichológiai jól-lét önértékelése) lényegesen alacsonyabb; 
- a Kasser és Ryan-féle Aspirációs Index alapján a börtönlakók körében hasonlóan a normál populációhoz (az alacsonyan iskolázottak és a fiatalok - 18-35 évesek kivételével) az egészségmegőrzése után az extrinsic célok (gazdagság, hírnév és jó megjelenés) bírnak jelentőséggel, kivéve a börtönbe vonulás előtt aktív foglalkozási csoportot (rájuk inkább jellemzőek az intrinzik - fejlődés, társadalom, kapcsolatok - célok, mint az inaktív csoportra);

- a társas támogatás tekintetében (Caldwell-féle társas támogatást mérö leltár) hasonlóan a többségi társadalom tagjaihoz a nyíregyházi börtönlakók nehéz élethelyzetben inkább számíthatnak a családon belüli (szülő, gyermek, házastárs, élettárs) kapcsolataikra, mint a nem családi (munkatárs, szomszéd, egyesület) személyes és csoportos támogatásra.

A 2008-as kérdőívet néhány kérdéssel kiegészítve ismételtük meg az adatfelvételt 2015 májusában. A kérdőív mellett félig strukturált kérdőívvel interjúkat is készítettünk, szándékaink szerint információkat gyüjtve az intézményben előzetes letartóztatásban lévők illetve fogvatartottak (börtönbüntetésüket töltők) körében többek között a jövőképükről, a siker értelmezéséről és a személyes hozzájárulásukról céljaik elérésében. ${ }^{3}$ Jelen tanulmányban a siker reprezentációját vizsgáljuk 13 fogvatartottal készített interjú elemzésével.

Az interjúkat az intézet könyvtárában készítettük, a magnófelvételről készült szöveges átiratban fókuszált kódolással (Charmaz, 1994) gyüjtöttük az adatokat, a kódok in vivo (pl. karrier, család, szülö, gyerek, barát, hit) és a szövegből illetve

${ }^{3}$ Az interjú narratív blokkjában az élettörténetükröl, életeseményekről, börtönkarrierről beszéltek az interjú alanyok. A második blokkban az alábbi kérdésekre vártunk választ:

1. Fogvatartása alatt mivel tölti a szabadidejét? (Ha nem nevez meg intézményi lehetöséget, akkor: miért nem veszi igénybe; Ha megnevezett intézményi lehetőséget, akkor értékelje).

2. Milyen egyéb lehetőségeket javasolna a szabadidő eltöltéséhez?

3. A fogvatartottak közötti problémákat hogyan lehetne kezelni, megoldani?

4. A fogvatartottak és a felügyelök közötti problémákat hogyan lehetne kezelni, megoldani?

5. A fogvatartottak és a nevelök közötti problémákat hogyan lehetne kezelni, megoldani?

6. A szabadulás utáni életet hogyan lehetne jól elökészíteni itt az Intézetben? Milyen programok, foglalkozások segítenének?

7. A szabadulás után milyen problémái lesznek Önnek?

8. Milyen tervei vannak a szabadulás után?

9. Ki vagy kik segítenek Önnek a sikeres kinti élethez? Mit tekint sikernek?

10. Miben kell (vagy kell-e) Önnek változni a sikerhez? 
a jelentésből alkotott kódok (pl. diszkrimináció, felelősségvállalás, tudatos jövőtervezés, sikerkép) voltak.

\section{Elemzés}

Az egyéni cselekvést motiváló sikerképzet nemcsak a saját képesség(ek)től és erőfeszítéstől, hanem az észlelt-becsült társadalmi mozgástértől is függ, és végső soron ezek együtt alakítják ki az egyén aspirációs szintjének referenciakeretét - írja Váriné Szilágyi Ibolya (2015). Az általunk megkérdezettek válaszaiban nem jelentek meg a társadalmi korlátok-elvárások, vagy a többségi társadalom értékrendje - mintha életük a korlátlan lehetőségek terében zajlana. Sikernarratíváikban az egyéni erőfeszítés, eltökéltség kap kulcsszerepet.

A fogvatartás utáni időszakban a megkérdezettek mindegyike hangsúlyozta a társas kapcsolatok elsősorban a Granovetter-i értelemben ${ }^{4}$ vett gyenge kapcsolatok (barátok, ismerösök) elszakadását, így céljaik megvalósításában föleg önmagukra és a szükebb családi környezetre tudnak támaszkodni.

\section{$K:$, ,... amig itt bent vagy kint kire támaszkodhatsz? A: Hát a családomra. Apuékra."}

Az előítéletesség széleskörü elterjedtsége ellenére többen bizakodva (a jövőbelátás illúziójával ${ }^{5}$ ) tekintenek a szabadulás utáni időszakra, bízva abban, hogy a közösségi vélemény megbocsátó, elfogadó vagy megértő lesz azzal szemben, aki ítélet szerint megszegte a törvényeket. A feltételezett büncselekményt, jogsértést szinte néhány, döntően erőszakos büncselekmény miatt elítélt kivételével a nagy

\footnotetext{
${ }^{4}$ Mark Granovetter: A gyenge kötések ereje: A hálózatelmélet felülvizsgálata; http://www.tankonyvtar.hu/hu/tartalom/tamop425/0010_2A_19_Tarsadalmi_retegzodes_olvasokonyv_szerk_Gecser_Otto/ch06s03.ht $\mathrm{ml}$ Letöltve: 2017.09 .12 .

5 „,... a bizonytalanság körülményei közepette az emberek döntéseikben nem követik a várható hasznosság hipotézisnek megfelelö elörejelzéseket. Ehelyett itéleteik meghozatalához néhány alapvetö heurisztikus eljárást és hüvelykujjszabályt alkalmaznak. ” Hámori Balázs: Kísérletek és kilátások David Kahneman címü cikkében idézi Kahnemant, a 2002. évi közgazdasági Nobel-díjas tudóst. Közgazdasági Szemle, L. évf., 2003. szeptember (779-799. o.) http://epa.oszk.hu/00000/00017/00096/pdf/3hamori.pdf Letöltés: 2016. 10.19.
} 
többség megmagyarázhatónak, a véletlenek egybeesésének, sőt tudatos átverésnek tünteti fel, ahol az elkövetők maguk is áldozatok (az okok között felsorolva pl. rossz társaság, rosszakaró, megcsúszás, átverés, stb.).

Mások a sorsot hibáztatják anélkül, hogy a személyes felelősség felmerülne.

„Úgy érzem, hogy ismétlödik velem a sors mindenben."

A felelösség elhárításának okai között egyrészt szerepelhet egyfajta elhárító stratégia a büntetés, a negatív megítélés csökkentése érdekében, másrészt bizalmatlanság a börtön-közösségen kívül állók, a kérdezöbiztosok irányában. Nem vethető el még az anómikus értékrend (az eredeti közeg normabontó kultúrája által megszabott értékrend), mely felmentést ad, de legalábbis a felelősség enyhítését jelenti.

„De én nem olyan büncselekményt követtem el, amiér' szerintem el lehessen itélni engem. Mer'én nem loptam meg senkit, becsületéböl nem vettem ki senkit."

Mindenesetre a 13 interjú alany közül egy fő tekintette a szabadulása utáni helyzet kulcsának a személyes változás szükségességét, ezzel elfogadva szerepét, felelősségét a jogsértés helyetti jogkövetés elérésében.

„Igen nagyon kéne megváltozzak, de nagyon nem is kicsit. Nekem csak az italról kéne lemondanom.").

A többiek saját maguk kritikai megközelítését elvetve, egyfajta önbiztatással növelik személyes respektjüket, számot se vetve a büntetés letöltése utáni kihívásokkal:

„,Tehát én-változásra minden embernek szüksége van változásra, mert olyan jó ember van, de nagyon kevés. De most én egészen jó embernek tartom magam egyébként."

A korábban bemutatott sikeres karrier típusok közül a szakértő (a szakmai tudás kiemelt szerepe) valamint az átmeneti típus jelenik meg többször az interjúalanyok siker narratíváiban.

„,Állást találok, mer' van különbözö tanfolyamjaim,.... oda szerintem bármikor felvesznek, mer' megvan egy pár, jópár gépkezelöi papirom."

A sikeres karrier megformálásában az egyéni és közösségi értékspektrumok sajátos mixe jelenik meg, ahol a tudás, a család, a biztonság mellett a gazdasági értékek elsőbbségével csorbul a normakövető értékrend:

„Csak...az a gond, hogy...nem biztos, hogy megéri nekem beállni dolgozni hivatalosan" 
Ez azonban utalhat az anomikus össztársadalmi értékrendre is, amelyben a teljesitmény értéke az értékrendszer inkább elutasított elemei között szerepel. (Prazsák, 2015)

A megkérdezett 13 fö közül kettőnél ismerhető fel a lineárisként megfogalmazott karrier út, ahol a tudásfejlesztés, szakmai kompetenciák növelése valamint a vállalkozás müködtetése, fejlesztése jelenik meg a siker elérésében.

„....mindenem az, hogy ezt a szivattyúgép-kezelöi tanfolyamot elvégezzem, és ha még lehetöségem lenne szeretnék egy olyan, hát egy valami szakmát szeretnék, amivel hát nagyobb lehetöségem lenne más munkára."

„,...van egy müködö vállalkozás, amibe én azt gondolom, hogy késöbb az ember majd fejleszteni tudja."

Interjúalanyaink többnyire felkészültnek érzik magukat a sikeres életre, úgy érzik a család és a tágabb közösség támogatásával képesek lesznek munkát szerezni és jövedelmet biztosítani a családjuk számára.

A jelen kutatás során megkérdezettek siker fogalmát és a mögöttes ideológiát az interjúk során nem sikerült részleteiben feltárni, és bár az önkitöltős kérdőívben szerepelnek értékrendre, élet értelmére vonatkozó kérdések a névtelenség miatt ezek a kérdések, illetve a válaszok nem kapcsolhatók össze az interjúban elhangzottakkal. A fogvatartottak siker narratíváikban a család támogató, biztos hátteret nyújtó szerepe mellett a büncselekményi felelősség elhárítását a jövő alakításában betölthető kulcsszerep veszi át. Ebben magabiztosak és a cél érdekében megfogalmazottak irányában elkötelezettek.

„, Családdal együtt mindenképpen valami munkát. Tehát nem vagyok egy elveszett ember. Ha valamilyen vagy, vagy felülök kamionozni, vagy nehézgépre felülök, még ezt nem tudom. Vagy külföld.",

„Nekem muszáj lesz talpra állni. Mert ez így nem jó, ez az élet. Túlságosan, itt benn nem."

A sikeres életben a börtön világából különösen nagy jelentőséget kap a család, a munka és a szabadság. Az elzárás, a szabadság korlátozása és a nem önként vállalt társas kapcsolatok mellett sokuknak megmaradnak a családi kötelékek, érzik a támogatást a család, helyi közösség részéről és biztosak a későbbi elfogadásban is, mindezek felerősítik a család iránti felelősség jelentőségét, ez tünik a legerösebb motiváló erőnek.

„,Munkahelyem legyen, a családomnak ne legyen hiánya semmiben. De a munkám által. Ne kelljen soha semmi törvényellenesbe nyúlnom ahhoz, hogy megtudjak nekik mindent adni." 
A sikeres élet megteremtésében számtalan életstratégia fedezhető fel, ezek hátterében más-más ideológiai elképzelések, gyakorlati élettapasztalatok, tudás és kultúra szerepelhet. Életstratégiánk függ attól, hogyan és milyen célt választunk életünknek, önmagamban vagy rajtam kívül keresem az élet értelmességét, mi határozza meg azt, hogy hogyan élek, gyakorlati vagy inkább elméleti megfontolások alapján alakítom jövőmet? Többek között ezekre a kérdésekre adott válaszok alapján különíthetők el a föbb alternatívák.

Hársing László szerint,

- vannak, akiknek életét eszmények, ideológiák irányítják, ebben szellemi menedéket találnak;

- mások a világ kettös természetéböl indulnak ki, a mulandóban az örököst, a fogyatékosban a tökéletest is látják;

- a következö típus a racionalitás híve, háttérbe helyezi az érzelmek-indulatok irányító hatását;

- a mindennapok élvezöje a gyakorlati következményekre fókuszál, elfogadja a folyamatos változás, a kompromisszum szükségességét;

- a világ, mint egész, a teljesség egy elemeként ismeri el önmagát a passziv életstratégia híve;

- a hedonisták az élvezetre koncentrálnak, az „élj a mának és élvezd az életet” hívei;

- a kalandkeresők aktív változtatók, keresik és elfogadják a kockázatokat;

- a belsö otthonra koncentrálók a „légy hü önmagadhoz” követői, saját személyiségüket helyezik az életük fókuszába;

- a lázadók életstratégiájában az értelem keresése jelenik meg, de ebben a keresésben magában a kiábrándultság, pesszimizmus, az élet értelmetlenségének gondolata van (Hársing, 2005).

A fenti alternatív életstratégia ideáltípusok tisztán nem különíthetők el az általunk megkérdezett büntetés-végrehajtásban szabadságukat töltő fogvatartottak között, részben az interjú kérdésfeltevései, részben a kérdező irányítása miatt, azonban egyegy motívum vagy jellemző motiváció tetten érhető a válaszok elemzése során.

A vallásos meggyőződés, bár a bünelkövetést nem akadályozta meg, segít az átmeneti nehézségek legyőzésében, ha nem is tekinthető mindenek felett álló irányító erőnek, befolyásolja a döntéseket.

„....cégemet is és ugye az életemet is vallásom szerint élem. Úgy nevelem a családomat is. Mind a két gyerek ugye... katolikus óvodába jártak." 
A kalandkereső életstratégia egy esetben ismerhető fel, ahol a normaszegést követő büntetés megtapasztalása ellenére is hajlandó a fogvatartott kockázatot vállalni a jobb élet (jövedelem) reményében.

\section{Összegzés}

Az interjúalanyaink többségénél egy sajátos életstratégia körvonalazható (a világ kettős természetét elfogadó életstratégia típus néhány eleme felismerhető itt). Egy, a korábbi tapasztalatokat (normaszegés, büntetett elöélet, közösségi konfliktusok, iskolai, munkahelyi kudarcok, stb.) kizáró, vagy figyelmen kívül hagyó idealisztikus világkép kerül a fókuszba, ahol a munkát akaró munkát kap, a család és a rokonság feltétel nélkül elfogad, támogat, s ezzel együtt egy hasonlóan idealisztikus önkép, a családjáért és önmagáért felelősséget vállaló családfenntartó férfi képe jelenik meg. Cselekvéseit tekintve ebben az életstratégia típusban a személyes készségek, hozzáállás megfelelő hátteret nyújt a sikerhez (nem szükséges a változtatás), a lehetőségek adottak, s a tervezéshez és végrehajtáshoz elegendő lehet a jövő elképzelése. Álmodozónak is nevezhetnénk, hiszen az elképzelés szerint voltaképpen minden megoldódik majd magától - csak kerüljön ki a fogvatartott a börtönből.

Egy 2000-ben elvégzett, hátrányos helyzetből induló, sikeres romák életútját tanulmányozó kutatás következtetése, hogy a sikeresség és ehhez kapcsolódó személyes elégedettség mögött küzdelmes, gyakran komoly hátrányos megkülönböztetéssel terhelt életutak vannak. „A siker fénytörései - Sikeres romák” címü könyvben bemutatott emberek, bár személyes sikereiket és kudarcaikat a kibocsájtó családhoz, a kiindulási helyzetükhöz mérten és a többségi-kisebbségi társadalom kapcsolatrendszerében értékelték, átélték a sikerrel járó elégedettséget, az akarat, szorgalom, elkötelezettség fontosságát hangsúlyozták. Sikereikben egyéni személyes erőfeszítéseiket és az elért teljesítményüket kulcsfontosságúnak tekintették, akkor is, ha ez sok esetben lelki és fizikai megpróbáltatásokkal járt együtt. A külső/többségi társadalmi tényezők elsősorban, mint kudarcfaktorok jelennek meg a megkérdezettek nyilatkozataiban (Székelyi és mtsai 2005). 
A börtönben megkérdezett interjúalanyainknak nem nagyon volt kétsége afelöl, hogy képesek sikeresek lenni a szabadulás után. A „Lát-e akadályozó tényezőt?” kérdésre adott válaszokban meg sem jelenik bármiféle kétely ${ }^{6}$.

Az egyéni kompetenciák mellett és azon túl további kérdések vetődnek fel a társadalmi környezet, értékrend és a bünelkövetö-normaszegő karrier kölcsönös viszonyában. A személyi viszonyokban testet öltő társadalmi tőke, mint a racionális cselekvés és a társas kapcsolatok által befolyásolt egyéni mozgástér megtestesülése, magába foglalja a kötelezettségeket, elvárásokat, megbízhatóságot-bizalmat, normákat és szankciókat (Coleman, 1988). Messze vezethet az a gondolat, hogy társadalmi tőke különböző szinteken megjelenő narratív disszonanciája mennyiben befolyásolja az egyéni döntéseket, a sikert, mint a társas viszonyok szférájában elérhető eredményt.

\section{Irodalomjegyzék}

1. Csepeli Gy (2010): Társadalmi szolidaritás - összetartó társadalom Letöltve 2017. 04.01. http://www.kka.hu/_Kozossegi_Adattar/PAROLAAR.NSF/e865e1 dacf38e2818525663b007896c5/e134d884d2d08cb5 c12577c00043cf1f?OpenDocument

2. Hársing L (1998): Nyitott gondolkodás - Filozófiai problémák - alternatív válaszok, Budapest, Eötvös J. Kvk. 207-215.

3. Charmaz K. (2013): Lehorgonyzott elmélet in Bodor Péter (szerk.) Szavak, képek, jelentés Kvalitatív kutatási olvasókönyv, Budapest, L'Harmattan. 61-94.

4. Larson R., Brousseau K. R, Kling K., Sweet P. L (2007): Building motivational capital through carreer concept and culture fit. Career Development International 12(4): 361-381.

Letöltve 2017. 04.01.

file://C:/Users/FELHAS 1/AppData/Local/Temp/Building_motivational_capital_through_career_conce.pdf

5. László J (2000): A szociális reprezentáció járványtanáról. Replika 41-42 (2000. november) Letöltve 2017.04.01.

\footnotetext{
${ }^{6}$ Pl. Richard St John TED-es előadásában (Technology Entertainment Design „A siker 8 titka") megfogalmazott kulcstényezők (értéket adni, szolgálni másokat; szenvedéllyel csinálni dolgokat; keményen dolgozni; a feladatra koncentrálni; kitartani a céljaink mellett; ötleteket megvalósítani; gyakorolni; erőfeszítéseket tenni) hiányoztak a válaszokból. https://www.ted.com/talks/richard_st_john_s_8_secrets_of_success
} 
http://www.tarsadalomkutatas.hu/kkk.php?TPUBL-A-634/replika/41_42/TPUBL-A-634.pdf

6. Murányi I (2012): Börtönlakók és a stressz in Murányi I, szerk. Ifjúságszociológiai Szöveggyüjtemény Debreceni Egyetem Szociológiai és Szociálpolitikai Tanszék. 87-113

Letöltve: 2016. 10.13.

http://mek.oszk.hu/14500/14536/14536.pdf

7. Prazsák G (2015): Marginális csoportok értékrendszerei. Kultúra és Közösség VI évf. 2015/I szám.

Letöltve: 2016. 07. 26.

http://www.kulturaeskozosseg.hu/pdf/2015/1/09.pdf

8. Schleicher N (2015): Narratív identitáskonstrukciók in Vita publica Tanulmányok Rényi Mária tiszteletére. ELTE TÁTK, Budapest. 169-191

Letöltve 2016. 07.26.

http://tatk.elte.hu/file/Vita_publica_2015.pdf 172.o

9. Asch S. E. (1998): A csoportnyomás hatása az ítéletek módosulására és eltorzítására in Erőss F (szerk.): Megismerés, elöítélet, identitás - Szociálpszichológiai szöveggyüjtemény Budapest, Új Mandátum Könyvkiadó. 17-36

10. Székelyi M, Örkény A, Csepeli Gy, Barna I (2005): A siker fénytörései Letöltve: 2016. 10.13.

https://www.academia.edu/18322143/A_siker_fénytörései._Sikeres_romák

11. Váriné Szilágyi I, Solymosi Zs (1995): A siker szociális reprezentációja értelmiségi rétegeknél Szociológiai Szemle, 25-54.

Letöltve 2016. 07.26.

http://www.szociologia.hu/dynamic/9501 varine.htm

\section{Dr. Pénzes Mariann}

térségi szakértő, Állami Egészségügyi Ellátó Központ.

Az ELTE TaTK Interdiszciplináris Kutatások Doktori Iskola doktorandusza 